\title{
Chapter 5 \\ Mediation and Conciliation in Collective \\ Labor Conflicts in Estonia
}

\author{
Mare Teichmann
}

\section{The Case}

27 employees of the HKScani Rakvere meat industry went on strike on October 17th 2017. The key issue at stake on this strike was the low wages. Negotiations between the employees and the employer were not successful. The employer accused the employees of doing an illegal strike, considering it didn't follow the Estonian law prescribes and there was not even a union in the company. The next day, the company informed that the strike was over. Three employees who organized the strike were fired. A head of HKScani Estonia promised that they would start negotiations on working conditions and wages. The next day, the strike promoters requested the Public Conciliator to solve the labor dispute. The employees quickly set up a local chapter of the trade union, which by October 24th had already increased its membership to 30 members. At the beginning of November, a meeting between representatives of the trade union and the management took place, in order to try to reach an agreement regarding the salaries. This did not happen. According to the Public Conciliator, management and employee representatives had often met to negotiate, and HKScani's management had previously informed her that they would do everything to resolve the conflict as quickly as possible.

"I am also disappointed with yesterday's results", the national mediator acknowledged Meelis Virkebau (Public Conciliator from 2017 until 2022) to a news portal on 7 th of November 2017, adding that he was not able to foresee such a move. "If one party says that the salary needs to be raised by $50 \%$ and the other party says zero per cent, and neither side gives up, they will never reach an agreement", said Virkebau (November 7th, 2017).

M. Teichmann ( $\otimes)$

University of Technology, Tallinn, Estonia

e-mail: mare@ pekonsult.ee

M. Euwema et al. (eds.), Mediation in Collective Labor Conflicts, Industrial Relations

\& Conflict Management, https://doi.org/10.1007/978-3-319-92531-8_5 
The employees started an untimely strike again on December 14th, 2017, where $3 \%$ of the employees joined the strike, and 90 of the 785 employees are members of the trade union in the company. The Industrial and Metal Workers' Trade Union (IMTAL) led the strike and the Estonian Trade Union Confederation (EAKL) supported it. A meeting was held between the board of HKSCani Estonia (the trade union of the company) and the Public Conciliator, which resulted in the closure of the conciliation process, since the parties were not ready to compromise. The strike lasted several months, without any progress.

In conclusion, "The labor conflict in the Rakvere company was caused by the lack of professionalism of the managers. Employees are not compensated enough, they have not been treated well enough and their wishes have not been taken into account. No matter how much you raise the wage, you cannot compensate the negative attitude with money", said national mediator Meelis Virkebau (14.12.2017). Meelis Virkebau, a national mediator, highlights that it is sad to look at the Rakvere company developments. His suggestion has been to raise the salaries about $16-20 \%$.

He is willing to continue negotiations only if the parties are ready to come closer to each other, even if only slightly. In mid-April 2018, the employees decided to stop the strike and return to work. The trade union points out that many problems have not yet been solved.

\subsection{Introduction}

In 2000 the Trade Union Law was adopted, which guarantees the right to organize unions. Union density is low in Estonia being around 10\% (OECD, 2018). Only a third part of employees are covered by collective bargaining in Estonia and by far the most important level for collective bargaining is the company or organization, with unions negotiating with individual employers. However, the minimum wage is set after negotiations between the union confederations and the employers at national level.

The legislation, which came into effect in 2007, allows for the election of employee representatives both where there is a union and where there is not. Estonia has a procedure in place for there to be an appointed working environment representative in more than half (54\%) of companies, in almost all $(99 \%)$ companies with 250 and more employees, and in a third of companies with 5-9 employees. A work environment council operates in 60\% of companies with 50-249 employees and in $90 \%$ of companies with 250 and more employees. There is a trustee in approximately $18 \%$ of companies, which is 5 percentage points more than in 2009 . The general meeting of employees normally elects members of local as well as members of European bodies linked with European Works Councils and the European Company. 
Employee representation on health and safety is provided through separately elected representatives, who in smaller companies act individually and in larger companies are part of a joint employer/employee committee. These representatives have the power to stop work if there is a direct threat to the employees' safety.

In fact, it is unusual in Estonia to strike. The history of strikes in Estonia is very short and there is no tradition of strikes. The right to strike is an integral part of contemporary labor law. The right to collective action in labor relations in Estonia, as the right to organize a strike, is guaranteed (Tavits, 2014). Moreover, during the past 25 years we have had four strikes, namely, in December 2003 there was an organized one-day teachers' strike demanding an 12\% increase of wage; in 2004 there was a 6-days strike carried out by the Estonian Railway Drivers Union' to increase 15\% of their wage; in March 2012 there was another strike of the teachers' supported by Estonian Transport and Road Workers' Trade Union; in October 2012 there was a medical doctors' and nurses' strike for higher wages and reduced workload organized by the Estonian Medical Association and the Estonian Health Care Workers Union for a wage increase. The two strikes in 2012 went on for weeks. In total, there were 10 warning strikes over an 11-year period, and the first warning strike took place in 1996 (European Foundation for the Improvement of Living and Working Conditions, 2004). Warning strikes, which can last up to one hour, have only occurred during a specific period (2002-2017) (European Foundation for the Improvement of Living and Working Conditions, 2017). On the other hand, the ban of strikes for public servants was prolonged for 15 years (Docherty \& Van der Velden, 2012). Strikes are prohibited for governmental authorities and other state bodies and local governments; as well as for the Defense League, courts, and rescue service agencies.

Since 1993 labor conflicts were resolved according to the Collective Labor Dispute Resolution Act, and labor disputes were resolved based on the Individual Labor Dispute Act (valid until 31.12.2017). The new Collective Labor Dispute Resolution Act was worked out and it came in force on the 1st of January of 2018. The New Collective Labor Dispute Resolution Act regulates the procedure for the resolution of collective labor disputes and the calling and organization of strikes and lock-outs. So, the amended Act brings along considerable changes to the work of the labor dispute committee. The amendments aim to contemporize the rules of settling labor disputes in order to comply with society's expectations. However, the aim is slightly contradictory in essence. On the one hand, more specific rules are required for the more effective protection of persons' rights and it inevitably complicates the dispute resolution rules. On the other hand, there is a desire to guarantee a continually simple, fast, and cheap resolution of labor disputes in Estonia. The labor dispute committee usually consists of three persons - the chairman (a Labor Inspectorate official), a representative of employees, and a representative of the employer. The managing bodies of the central associations appoint the participants. The labor dispute committees shall begin to offer a new type of service-conciliation proceedings. In the case of the conciliation proceedings, the chairman of the labor dispute committee shall act as the sole conciliator, who proceeds with the purpose of concluding a conciliation agreement. In addition to this, collective labor disputes may be resolved in a labor dispute committee or court. 
According to the Collective Labor Dispute Resolution Act, a collective labor dispute is a disagreement between an employer or an association or a federation of employers and employees or an association or a federation of employees, which arises upon the entry into, or the performance of collective agreements or the establishment of new working conditions. The parties in a collective labor dispute are an employer or an association or a federation of employers, and employees or an association or a federation of employees. Employees or an association or a federation of employees are represented by the person authorized thereby (hereinafter representative of employees). In Estonia, there are four types of employee representatives:

(1) Employee representative as trustee-employee who is elected at the general meeting of employees to represent the interests of the entire staff;

(2) Trade union - an association formed by employees whose main purpose is to protect the interests of its members;

(3) Work Environment Representatives-Work Environment Commissioner and Working Environment Council;

(4) According to the European Parliament directive 2009/38/EU, the representatives of employees of an EU-scale conflict are employees chosen to represent the employees of the whole company. Special laws regulate responsibilities and activities for all four different representatives.

The main task of all different employee representatives is to cooperate and to provide the knowledge and skills needed to better represent employees' interests in all spheres of the working life (Tööelu, 2017).

Our study findings demonstrate that in the very beginning i.e. in an early stage of work-related collective conflicts, employees try to resolve conflicts by using mediators within the organization. It was common to choose a mediator among the direct managers, human resources specialists or HRM, employees' representatives, trade union representatives, etc. If such "home-made mediation" process is not successful, conflicting parties choose among three legal options for work-related conflicts. The first option is to resolve the labor dispute in a Labor Dispute Committee. A labor dispute committee is an extrajudicial authority within the Labor Inspectorate that manages collective labor disputes arising from the application of a collective agreement (collective labor dispute). A labor dispute committee shall be independent and base its decisions on laws and other legislations, or international agreements binding Estonia and other regulations that govern employment relationships, including collective agreements and employment contracts. However, mainly it concerns procedures and conditions for the resolution of an individual labor dispute between an employee and an employer or some employees and employer. A labor dispute committee is active at the local inspection of the Labor Inspectorate.

Local inspectorates of the Labor Inspectorate are:

(1) the Eastern Inspectorate, whose areas of operation are the Ida-Viru County and the Lääne-Viru County-the location is Jõhvi;

(2) the South Inspectorate, whose areas of operation are the Jõgeva County, the Põlva County, the Tartu County, the Valga County, the Viljandi County and the Võru County-Tartu; 


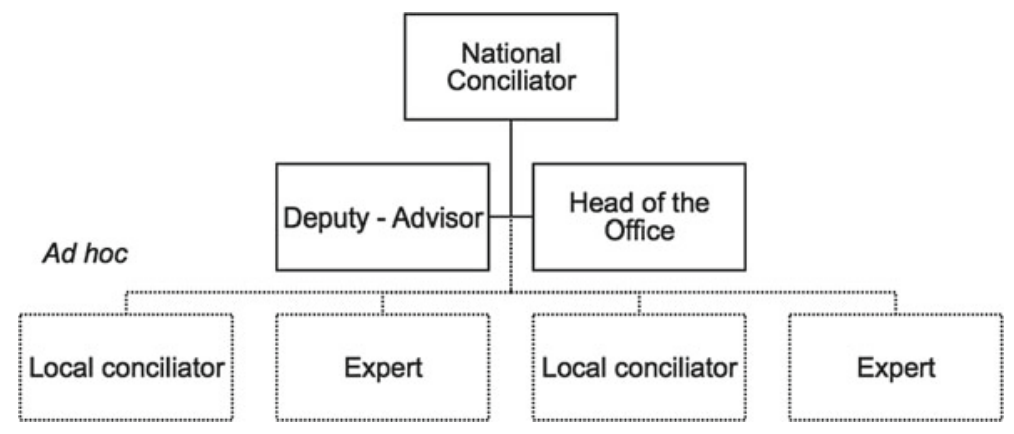

Fig. 5.1 The Public Conciliator Office

(3) the Western Inspectorate, whose areas of operation are the Hiiu county, the Saare county, the Järva county, the Lääne county, the Pärnu county and the Rapla county-location Pärnu;

(4) the Northern Inspectorate, whose area of operation are the Harju County, which is located in Tallinn. It is forbidden to lodge an application both with a labor dispute committee and a court. According to the new Collective Labor Dispute Resolution Act the Labor Dispute Committee shall be empowered to settle the collective labor disputes arising from the execution of a collective agreement.

At the request of the parties in the collective conflict and/or for resolving more serious collective labor conflicts, a Public Conciliator can be called, especially when negotiations between conflicting parties themselves within the organization fail to produce a result and there's a risk of strike. There's an additional option: to ask the Public Conciliator Institution for labor conflict mediation. Apart from the Public Conciliator, there are also local conciliators (Fig. 5.1).

The Public Conciliator in the event of a collective labor dispute (mainly in a dispute regarding the terms of a collective agreement) is an impartial expert who helps those involved in the labor dispute to reach a compromise. The limits of the competence of the Public Conciliator to reconcile employers or employers' associations or associations and employees or associations of employees (hereinafter the parties to the labor dispute). The conciliation procedure is the way and order of organizing the legal acts performed in conciliation between the parties to the labor dispute. The national conciliator shall begin the conciliation procedure with a view to identifying the causes and circumstances of the case:

(1) hear separately the positions of both parties in the labor dispute arising;

(2) requests the documents necessary for the conciliation operations of the working groups, institutions and enterprises and other organizations and officials;

(3) involve experts or other experts and officials competent to resolve the dispute for the assessment of circumstances and documents;

(4) verify and analyze the submitted documents. 


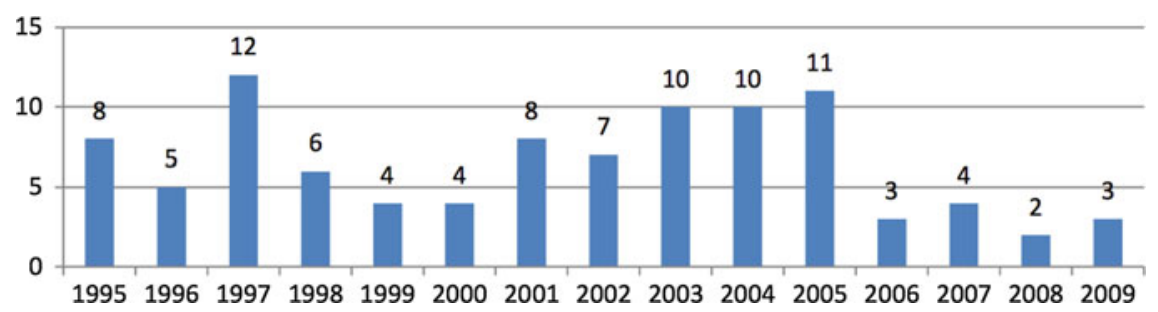

Fig. 5.2 The number of requests for conciliation submitted to the Public Conciliator. Source Overview of Public Conciliator Documents (Kallaste \& Kraut, 2010)

There are not too many cases resolved by Public Conciliator (Fig. 5.2). For example, the former Public Conciliator Henn Pärn (2001-2003 and 2006-2017) resolved about 100 cases (Employers, 2017). Most disputes over wages and collective agreements managed by the conciliator end with a positive result. According to the Public Conciliator's Office, agreement is achieved in $80 \%$ of all cases (European Foundation for the Improvement of Living and Working Conditions, 2004).

And finally, the third option is to turn to court. There are no specialized courts in the form of employment courts in the Republic of Estonia. All labor disputes lay within the jurisdiction of general courts, but in larger county courts there is a trend towards specialization, which also includes labor disputes. In general, the number of labor disputes, including individual disputes brought to court has remained quite similar for some years. For example, in 2013, 451 labor disputes were brought to court; in 2014 the number of cases was 375; in 2015 there were 386 cases (Kohtute statistika, 2015). In respect of labor disputes, no separate court statistics are kept in the Republic of Estonia. The majority of labor disputes concern termination of the employment contract, especially due to a lay-off or failure to manage the probationary period, as well as the claims for underpaid wages/salaries or benefits.

\subsection{Characteristics of the System}

In the case of labor disputes it is possible to choose among three legal options for resolving work-related conflicts outside the organization: (a) to apply to the labor dispute committee, (b) to ask the Public Conciliator Institution for conflict mediation or, (c) to turn to court. Under the Estonian law, conciliation is voluntary. Despite the fact that there are so many actors, the rights of a significant number of employees in the employment relationship might not be protected enough. The empirical evidence shows that up to one fifth of the employees will not try to solve the problems that may arise in the employment relationship, and about one tenth did not know whom to turn to in order to get help for solving their work-related problems (Masso et al., 2013). 
First Step: Internal Mediation.

The most common option when there is a disagreement between an employer and an employee or between employer and the group of employees, as attempts should be made to resolve the dispute by agreement of the parties. Accordingly, in the interviews the parties expressed a clear position that work-related conflicts should be resolved within the company, and bring in external help.

The main factor hindering the use of mediation is poor knowledge of the subject by managers and also the cultural context. I think that our culture is not very susceptible to change and/or adapt the new forms of resolving company-related problems. Distrust of outsiders and connected business secret, intellectual property and data protection issues also probably have its impact.

Resolving conflicts by using help of mediators is not very popular in Estonia. But nowadays wage pressure and need for better working conditions could make unions and mediators more relevant and necessary.

Third party interventions are usually used in court proceedings, when the court involves specialists to help resolve a conflict between parties. As far as I am aware, professional mediation is seldom used, or if it is, then it is not widely publicized. The alternative form of dispute resolution more often used is arbitration.

It is the main reason why parties look for trustful "home-made" mediators inside the company. It is common to choose a mediator among direct managers, human resource specialists, employees' representatives, or trade union representatives. One of key disadvantage of such "home-made" mediators is that they do not have proper knowledge and skills for mediating work-related conflicts. In the study, the professional qualities of the mediators in general were evaluated as hardly satisfactory. Moreover, "home-made" mediators were sure that mediating and resolving conflicts are tasks of their job and it is not necessarily needed to have special training.

Mediating conflicts comes within my specialization. It is closely involved with my different job tasks, where as a personnel manager, I have to sometimes find solutions to the collective problems what occur between the employees and the employers, where personnel manager is the so called middle man in between. I haven't been trained as mediator" (HR specialist, elected trustee).

\section{Second Step: Labor Dispute Committee.}

If the dispute cannot be resolved by an agreement of the parties and before turning to court, both the employer and the employee or employer and employees have the right to present the case to a Labor Dispute Committee. Labor dispute committees are formed at each local inspectorate of the Labor Inspectorate. Still, it is common understanding that these outside mediators from the Labor dispute committee or Public Chancellor Office are needed when conflicts are too serious and disagreements are related to whistleblowers from the company.

I think that mediators are invited only when the problem is under high media pressure. Until there is no media attention, the external mediators are not very common.

I know that our company does not use mediators outside the company (no need to). I know that in Estonia there have been cases when to use mediation and it had been also in media (the news). Most of conflicts are solved within organization. 
In the case of individual labor disputes, the parties wishing to protect their rights can either approach a Labor dispute committee comprising the representatives of employers and employees or a court of first instance, i.e. a county court. There are no trade union representations in individual labor disputes in Estonia.

A Labor dispute committee is a pre-trial independent body, which operates pursuant to international agreements in force in Estonia, the law, administrative acts and other rules regulating employment relationships, and also collective agreements and employment contracts. A labor dispute committee is competent to resolve a dispute if the chairman of the committee and at least one representative of employees and one representative of employers participate in the work of the committee. The chairman of a labor dispute committee shall invite an equal number of representatives of employees and representatives of employers to participate in the work of the committee. In the cases provided for in this Act, the chairman of a labor dispute committee is competent to resolve a dispute alone. If the parties do not agree with the decision of a labor dispute committee, they have the right to bring a court action within 30 days of the receipt of the decision of the labor dispute committee.

The New Collective Labor Dispute Resolution Act regulates collective labor disputes in Estonia. If there's a failure to reach agreement on collective labor disputes, the employers and representatives of the employees have the right of recourse to federations of employers and federations of employees, which will, within three days after the date following receipt of an application, establish a committee on a basis of parity for resolution of a labor dispute and shall notify the Public Conciliator thereof.

Third Step: The Public Conciliation Institution.

The third option for resolving labor disputes is to involve the Public Conciliator Institution. The structure of this institution includes a Public Conciliator and local conciliators from different counties and cities. The activities of the Public Conciliator institutions are based on the Collective Labor Dispute Resolution Act, the Collective Agreement Act and the Statute of the Conciliator on Collective Labor Disputes. The Public Conciliator coordinates the activities of local conciliators and solves interdependently complicated work-related conflicts, and local conciliators deal with local collective labor disputes. The parties of the disputes related to the conclusion and performance of collective agreements have the right to consult the Public Conciliator. The Public Conciliator is a person appointed by the Government of the Republic, who shall try to identify the reasons for a labor dispute and shall propose resolutions. In case of successful negotiations the conciliation shall be documented and the performance of the agreement is binding for both parties.

The Public Conciliator institution has been operating since 1995. The Public Conciliator is an independent impartial official who helps the parties reach mutually satisfactory resolutions. The Public Conciliator shall identify the reasons for and the circumstances of a labor dispute and propose resolutions.

If there's failure to reach an agreement between a federation of employers and a federation of employees in a dispute arising from the performance of a collective agreement, the federations have the right of recourse to a labor dispute committee or 
the court for the resolution of the dispute. The organization of strikes or lock-outs is prohibited as of the date of recourse to a labor dispute committee or the court. Court rulings are made in writing in Estonia. The labor dispute committee shall review an application within one month of the day following the receipt of the application. Upon applying to the court, there is no period for taking consideration of the action provided for in the law. Therefore there are also no sanctions in place. The law prescribes the principle that civil cases shall be taken in accordance to a reasonable period, but it depends on the complexity of the case and the judge's workload.

\section{Forth Step: Going to Court.}

It is prohibited to apply for a labor dispute committee in parallel to attending court. The same procedures apply for collective conflicts. The Republic of Estonia has a three-level court system, comprising courts of first instance-county courts, circuit courts, courts of appeal and the Supreme Court-the Supreme Court of Appeals. County courts have separate courthouses. The circuit court has three chambers, i.e. Civil Chamber, Criminal Chamber and Administrative Chamber. Parties don't need a representative in a court of first instance or in a court of appeal. In the Supreme Court the parties must have a representative-an attorney at law. No state fee is applied for this resolution.

\section{Evaluation of stakeholders on the system}

The assessment indicates that the system for resolving labor conflicts does not work as well as expected by users. The shortcomings of the collective labor disputes system stakeholders were considered mainly due to: the lack of training i.e. mediator does have not enough competence, poor organization of work-related conflict resolution, belief that only big companies could use outside mediators, mistrust, negative experience with using mediator in work-related conflict resolution, and negative attitude towards third party mediation that means unwillingness to bring conflict outside of organization.

As far as I understand it is quite badly organized and structured. Many of the mediators do not have any kind of formal training.

In Estonia we have Collective Labor Dispute Resolution Act to regulate collective work conflicts and there is possibility to turn to Employers' Confederation or Employees' Confederation. Unions aren't very common in Estonia and their power is quite low in society compare with other European countries.

In Estonia, I think, we have very little interventions by the third party. This situation takes place sometimes only in the big companies which are also usually international companies. The trained mediators and the national conciliators don't have good reputation and popularity in Estonia. I think it is because our country has grown out from the Soviet Union background, where these kind of labor unions were not respected my people and made its mark to our memories and behavior. Also our media usually don't show the unions in a good tone.

Using third party invention on a conflict situation is maybe not as popular as it could be. Related probably to distrust, general fear of internal things "getting out", low conflict management skills in general. Successful conflict management means acknowledging the difficult situation and the fact that due to a conflict one or the other side (or both sides) needs to either change or even leave. 


\subsection{Characteristics of the Mediators or Facilitators and the Third Party Procedures}

Our study findings demonstrate that in early stage of work-related conflict, employees try to resolve conflicts by finding and using the mediators within the organization. It was common to find a mediator for work-related conflicts among direct managers, human resource specialists or HRM, employees' representatives, trade union person etc. The strength of such "home-made" mediators is trust, but the disadvantage is the lack of special training for mediating.

The boom of Alternative Dispute Resolution initiatives and regulations in Europe has been marked by a slow progress in achieving their potential, even, and apparently more so, in the countries that first implemented the European Union Directive 2008/52/EC: Portugal, Italy, France and Estonia (De Palo and Trevor, 2012). The (Mediation) Directive prompted work on the Estonian "Conciliation Act" that was passed on the 18th of November 2009. The expected increase in the use of ADR and mediation did not follow. This situation can easily be associated to the lack of a consolidated ADR culture in the country, as well as to the actual shortage of experts and/or enthusiasts that could promote mediation as the expedite, effective and non-intrusive assisted negotiation procedure that it could be (Solarte-Vasquez, 2014).

\subsection{Description of the Facilitation and/or Mediation Process}

According Collective Labor Dispute Resolution Act the collective labor dispute is a disagreement between an employer or an association or a federation of employers and employees or an association or a federation of employees which arises upon the entry into or the performance of collective agreements or the establishment of new working conditions.

At organizational level, a shop steward can be involved in a mediation process, but usually conflicts are resolved in Labor Dispute Commission (see Fig. 5.3).

Since the early 1990s, Estonia has created a system for the resolution of individual and collective labor disputes, involving labor dispute commissions, local conciliators, a public conciliator and the courts. In general, in case of collective labor disputes for conflicting parties there are four options to resolve their conflict with the help of mediator outside the organization. First, to turn to Labor Dispute Committee, as a party of labor conflicts, the second option is to involve Federations of Employers and Federations of Employees, third option is to ask for mediation from Public Conciliator Institution, and finally, always exists an option to turn to court.

The Public Conciliator and local conciliators have the responsibility to conciliate between parties during a labor dispute. The Public Conciliator is appointed for three years by the government on the basis of a joint agreement between the Ministry of Social Affairs and central federations of employers and trade unions. The public 


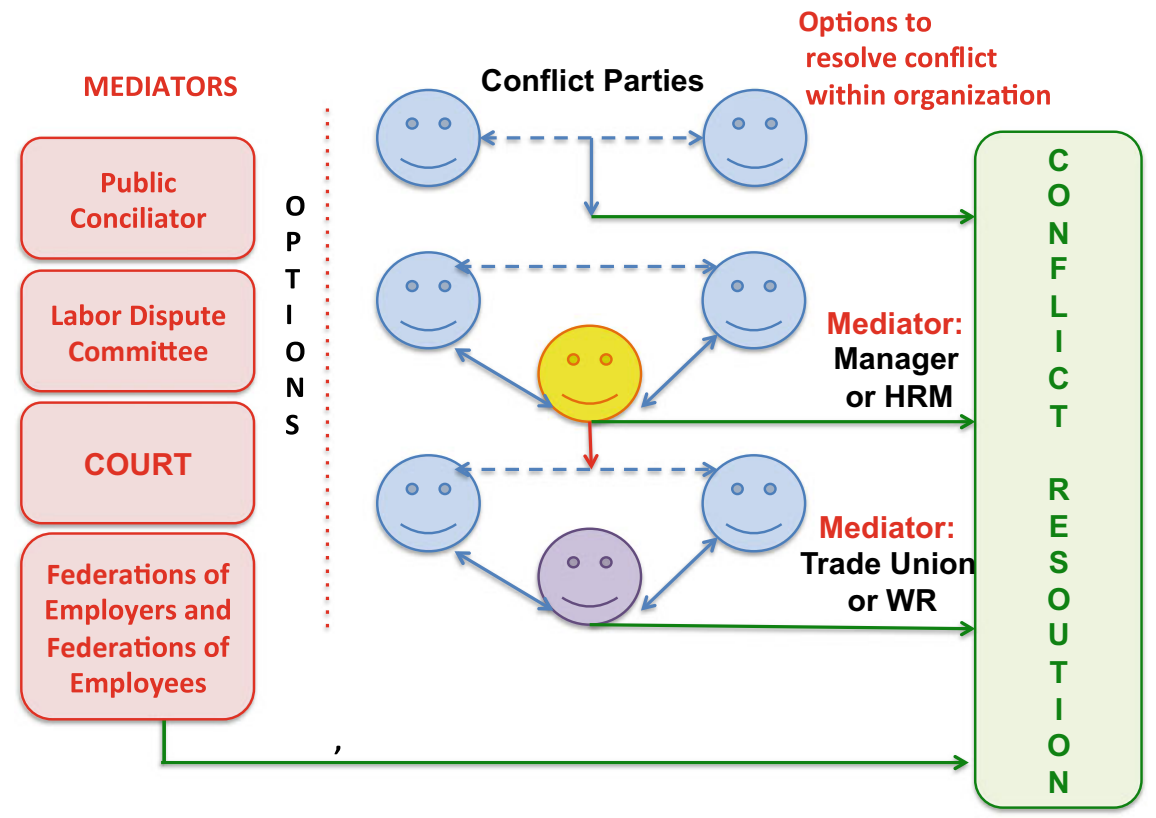

Fig. 5.3 Mediation options

conciliator appoints local conciliators for the resolution of a labor dispute in prior coordination with the local government authorities. Individual as well as collective labor disputes at organizational level are resolved primarily by the local conciliators, while labor disputes between federations of employers and unions are resolved by the Public Conciliator.

The courts may also resolve individual and collective labor disputes. Estonia has a three-tier court system: rural and city courts; district courts; and the state court (which functions as a supreme court).

For getting the third party outside the organization the employer or group of employees have to choose and apply the mediator. For example, in Labor Inspection Web page the applicant can fill an electronic application (see Fig. 5.4).

The duty of a conciliator is to effect conciliation between the parties. A conciliator should identify the reasons for and circumstances of a labor dispute and propose resolutions. Conciliators have the right to invite the parties to participate in conciliation proceedings, and to engage qualified persons or experts and competent officials in their work. Conciliation is effected through the mediation of a conciliator or on the basis of a proposal made by a conciliator. The parties must reply to the proposal made by a conciliator within three days. Parties are required to participate in conciliation proceedings, send their fully authorized representatives to participate in the conciliation proceedings and submit documents necessary for the substantive resolution of the matter by the date specified by the conciliator. The conciliation process is 


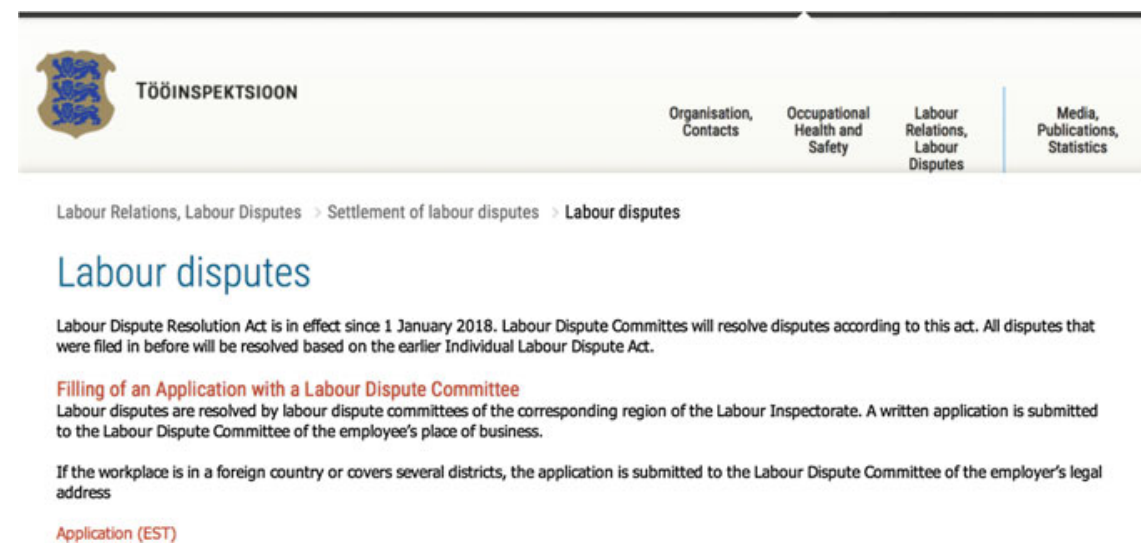

Fig. 5.4 At Labor Inspection Web page the applicant can find electronic application

documented by a report, which should be signed by the representatives of the parties and the conciliator. A conciliation outcome contained in a signed report is binding on the parties and enters into force upon signature, unless a different date is agreed on. The report should also be prepared in those cases where no agreement is reached.

\subsection{Effectiveness of the System}

Majority of work-related conflicts are solved at the organizational level. However, half of the disagreements were started off by the employees' dissatisfaction with payment conditions, followed by disagreements with collective agreements, labor legislation, working conditions and social guarantees. Most of the disputes about wages and collective agreements which have been in the conciliators' proceedings ended with positive results.

Also majority of collective industrial disputes are resolved in local industrial dispute commissions or by local conciliators, who are aware of local problems and are able to solve the problems more objectively. In the majority of cases of industrial disputes an agreement is achieved.

However, the satisfaction with mediation process is not high.

Third party interventions in case of conflicts, regarding work-related conflicts, are needed and have proven to be useful in my experience. At the same time it seems to me that the topic is underdeveloped in Estonia and in one case (it was about employment contract) I was part of I could say that the invited mediator failed to help the case. 


\subsection{Conclusions}

Estonia reformed its industrial relations system during the transition period, establishing new mechanisms for resolving individual and collective industrial disputes and for regulating strikes. Estonian labor laws dealing with organized labor are in accordance with the Constitution of Estonia, ILO Conventions and other international acts.

Mediation is a form of alternative dispute resolution, a way of resolving disputes between two or more parties with concrete effects. Different laws concerning industrial relations were adopted and amended over the transition period and different institutions dealing with industrial relations were established. The main institutions dealing with conflict resolution are the industrial dispute commissions, the public conciliator and local conciliators, and the court. Industrial disputes are generally resolved through direct negotiations between employers and employees. From 1st of January 2018 the new Collective Labor Dispute Resolution Act become in force, it specified significantly how to resolve collective labor conflicts.

The main reason for relatively 'peaceful' industrial relations in Estonia could be the fact that employees are still relatively weak. As noted earlier in this chapter, a considerably body of evidence has shown that exists a strong attitude toward resolve work-related conflicts within organization, even by using unprofessional "homemade" mediators.

\section{References}

De Palo, G., \& Trevor, M. B. (Eds.). (2012). EU mediation law and practice. OUP Oxford.

Docherty, J.C., \& Van der Velden, S. (2012). Historical Dictionary of Organized Labor. The Scarecrow Press Inc.

Employers (2017). New Public Conciliator Meelis Virkenbau. Retrieved from Employers: https:// www.employers.ee/uudised/meelis-virkebau/.

European Foundation for the Improvement of Living and Working Conditions (2004). Social dialogue and conflict resolution in Estonia. Retrieved from: http://edz.bib.uni-mannheim.de/wwwedz/pdf/ef/04/ef0449en.pdf.

European Foundation for the Improvement of Living and Working Conditions (2017). Living and working in Estonia. Retrieved from Eurofound: https://www.eurofound.europa.eu/country/ estonia.

Kallaste, E., \& Kraut, L. (2010). Riikliku lepitaja dokumentidel põhinev lepitaja tegevuse ülevaade CENTAR. Retrieved from: http://www.centar.ee/uus/wpcontent/uploads/2011/03/ Riikliku_lepitaja_dok_analyysi_raport.pdf.

Kohtute statistika. (2015). Retrieved January 20, 2019, from Eesti kohtud: https://www. kohus.ee/sites/www.kohus.ee/files/elfinder/dokumendid/i_ja_ii_astme_kohtute_2015.a_ menetlusstatistika.pdf.

Masso, M., Järve, J., Nurmela, K., Anspal, S., Räis, M.L., Uudeküll, K., \& Osila, L. (2013). Töölepingu seaduse uuring. Retrived from Poliitikauuringute Keskus Praxis: http://www.praxis. ee/wp-content/uploads/2014/03/2013-Toolepingu-seaduse-uuring.pdf.

OECD (2018). Trade Unions: Union members and employees. Retrieved from OECD Employment and Labor Market Statistics: http://dx.doi.org/10.1787/data-00323-en. 
Solarte-Vasquez, M. C. (2014). Reflections on the Concrete Application of Principles of Internet Governance and the Networked Information Society in the European Union Institutionalization Process of Alternative Dispute Resolution Methods. In Regulating eTechnologies in the European Union (pp. 251-283). Springer, Cham.

Tavits, G. (2014). The Right to Collective Action in Labor Relations in Estonia: Is the Right to Organise a Strike Guaranteed? Juridica, 21, 281-310.

Tööelu (2017). Representing employees. Retrieved from: http://www.tooelu.ee/en/ Employee/Working-relations/Representing-Employees-and-Collective-Working-Relationships/ Representing-employees.

Open Access This chapter is licensed under the terms of the Creative Commons Attribution 4.0 International License (http://creativecommons.org/licenses/by/4.0/), which permits use, sharing, adaptation, distribution and reproduction in any medium or format, as long as you give appropriate credit to the original author(s) and the source, provide a link to the Creative Commons license and indicate if changes were made.

The images or other third party material in this chapter are included in the chapter's Creative Commons license, unless indicated otherwise in a credit line to the material. If material is not included in the chapter's Creative Commons license and your intended use is not permitted by statutory regulation or exceeds the permitted use, you will need to obtain permission directly from the copyright holder. 